\title{
SELECTED ASPECTS IN THE CREATION OF THE UNIVERSITY'S KNOWLEDGE TRANSFER CAPACITY
}

\begin{abstract}
Summary
The paper is devoted to the analysis of the creation of university's potential for knowledge transfer to the business environment. The analysis will be presented in the system inspired by the model proposed by Tidd, Bessant and Pavitt [2005] which is as follows: (i) generating knowledge (ii) searching for and identifying knowledge, (iii) evaluating and selecting ides, (iv) implementing in practice. Each stage creates different challenges for the university's operations (also the final stage, which is not generally carried out by the university), which will be included in the analysis.

The results of the theoretical analysis are referred to the results of the research concerning knowledge transfer practices among universities in Lodz. A total of thirty-five cases of knowledge transfer practices were included in the analysis. The analysis conducted in 2010 and 2011 covered types of practices, the initiative of carrying out practices, their duration, the nature of practices, their subject scope and impact as well as risks and benefits associated with implementing knowledge transfer practices. The preliminary exploration, interviews and innovation studies conducted indicate that the analysis covered a vast majority of such practices, which means that it is representative of the Lodz region.
\end{abstract}

Key words: universities, innovation process, knowledge transfer.

\section{Introduction}

The development of the modern economy is largely generated by innovations. New solutions generated by the R\&D sector provide strong support for innovativeness of the economy [Drucker, Goldstain, 2007]. Hence, the need for capitalization of expenditure on education at the macroeconomic level, which results, among other things, from trends occurring in the context of the modern economy, is indicated. However, it is pointed out in many areas that knowledge derived from the widely understood sphere of science is not automatically commercialized in the form of new products or services. The enormous complexity of the process of knowledge commercialization in the case of universities is emphasized [Łobacz, Niedzielski, 2015], as well as the complexity of

\footnotetext{
${ }^{1}$ Paweł Głodek, Ph.D. - Department of Entrepreneurship and Industrial Policy, Faculty of Management, University of Lodz, e-mail: glodek@uni.lodz.pl. Dr hab. Edward Stawasz, prof. UŁ - Department of Entrepreneurship and Industrial Policy, Faculty of Management, University of Lodz, e-mail: stawasz@ uni.lodz.pl.
} 
processes of knowledge implementation and its dissemination. This fact hinders detailed understanding of these processes, in particular precise identification of individual "transactions" that show how the process of knowledge transfer occurs and even what the university's potential in this area should be [Etzkowitz et al., 2000].

The university is one of the parties in the process of knowledge transfer. The level of its preparedness to participate in this transfer is one of the factors determining the ultimate success [Hughes, Kitson, 2012]. Hence the aim of this paper is to present factors that determine the creation of the university's potential for knowledge transfer to the business environment. The analytical system inspired by the model proposed by Tidd, Bessant and Pavitt [2005] will be used in the analysis.

The results of the theoretical analysis are referred to the results of research concerning practices of knowledge transfer among universities in Lodz. A total of thirty-five cases of knowledge transfer practices were included in the analysis. The analysis conducted in 2010 and 2011 covered types of practices, the initiative of carrying out practices, their duration, the nature of practices, their subject scope and impact as well as risks and benefits associated with implementing knowledge transfer practices. The preliminary exploration, interviews and innovation studies conducted indicate that the analysis covered a vast majority of such practices, which means that it is representative of the Lodz region.

\section{The university in the context of management of innovation processes}

The university is a source of knowledge in the process of knowledge transfer. Its potential to generate solutions of suitable quality, the scope and potential of academic entrepreneurship as well as the potential for cooperation determine to a large extent transfer opportunities [Cieślik, 2014; Matusiak, 2010].

In this context, it should be stressed that ensuring effectiveness of the university's functioning in various types of partnerships with companies requires organizational activities associated with the creation of sufficient quantity and quality of organizational processes within the university. Woźniak [2014] points out in this context the process approach as one of the elements of building the university's competitiveness. The process approach is particularly advisable for management of knowledge within the university. Morawski [2005] indicates a number of factors that interfere with processes of knowledge circulation within the university, among its employees and organizational units. Lobacz and Niedzielski [2015] point to the existence of significant barriers within the university that restrict acquisition of information directly related to commercialization of knowledge.

Tidd, Bessant and Pavitt [2005] emphasize that innovation and the related exchange of information should be an object of management within an organization. It is necessary to introduce rules that allow to support favorable behaviors and attitudes, reduce adverse behaviours, introduce procedures, as well as implement and coordinate the desired processes. Outlining general guidelines for management of innovation processes in the enterprise, Tidd, Bessant and Pavitt [2005] indicate the need for effective implementation of at least three types of activities by innovative entities (Chart 1): (i) 
searching for and identifying new ideas (project planning), (ii) evaluating and selecting ideas/projects, (iii) implementing in business practice. It should be emphasized that from the point of view of management, these are interdependent areas - efficient management of each of the areas affects the possibility of achieving favourable results in the remaining ones.

CHART 1.

The general structure of the process of acquisition and commercialization of ideas within an organization

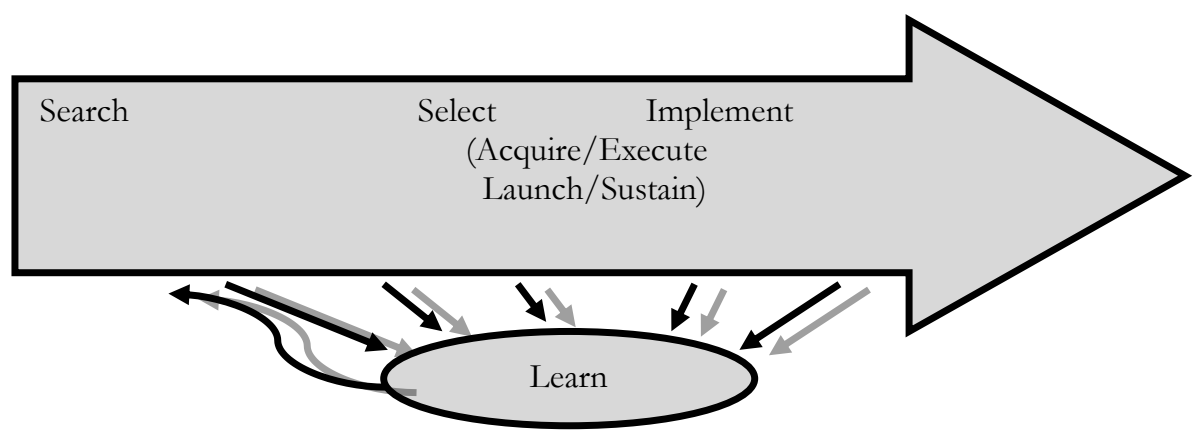

Source: [Tidd, Bessant, Pavitt, 2005].

On the other hand, imperfections in the implementation of one of the stages severely reduce effectiveness of the overall process. In simple terms it can be said that a lack of identification of ideas prevents their evaluation and possible application in practice, even if the organization is well prepared for their implementation. Thus, the stages of the process should be considered as interdependent. A key challenge in managing innovation is to find appropriate methods of carrying out these activities within the given organization (embedding them in structures and processes) to be able to replicate them efficiently and effectively [Bessant, Oberg, Trifilova, 2014; Trzmielak, 2013]. The organization's innovative success also requires the ability to review these procedures, their extension or change - i.e. dynamic capabilities [Teece, Pisano, Shuen, 1997].

Adapting this model to the university's realities, one must take into account its unique specificity, referring in particular to its focus on research and a lack of orientation towards commercial exploitation of research results. Research activity is one of the basic functions of the university and its effect is generating new knowledge. This knowledge, created largely in the context of basic research, should also be subjected to management processes to constitute a basis for its transfer outside. Knowledge management in this context can be understood as a process of identifying, acquiring and multiplying knowledge within an organization in order to improve its competitiveness [Von Krough, 1998]. The objective of knowledge management has, therefore, a very practical dimension relating to the need to support organizational capabilities through better utilization of individual and collective knowledge in the organization. These resources include skills, abilities, experience, routine, standards and technologies [Probst, 1998]. 
An important factor, which constitutes a significant specific feature of the university, is the fact that its only function is to generate and develop knowledge. The process of commercialization does not occur within the university as a rule. It is the domain of external partners, hence the process of managing innovation processes at the university should take into account processes related to seeking knowledge that can create value for external partners, as well as its actions concerning management of knowledge transfer.

Taking into consideration the above-presented considerations, with respect to innovative processes within the university, four stages will be taken into account: (i) generating/creating ideas, (ii) searching for and identifying ideas (project planning), (iii) evaluating and selecting ideas/projects, (iv) implementing in business practice.

The application of the process approach will allow the analysis and comparison of institutional solutions relating to commercialization of knowledge, including cooperation with companies, used in the framework of universities. Cooperation with companies is taken into account as an important component of the process of knowledge commercialization.

\section{The university - institutional solutions and their interconnections}

The use of perspective related to the innovation process enables to carry out an analysis of institutional solutions associated with knowledge transfer to the business environment functioning within universities. Various forms of mutual relations between the university and businesses are of key importance in this regard [Lawton, Smith, 2006], therefore, this area of cooperation in particular has been taken into account as an important component of the process of knowledge transfer.

The following elements have been taken into account as the existing institutional solutions in the area related to processes of creating the university's potential of knowledge transfer to the environment: (i) dean's representative for business relations, (ii) university chancellor's representative for business relations, (iii) innovation broker, (iv) creation of publicly available databases, (v) university technology transfer center, (vi) academic technology incubator, (vii) a university network of knowledge scouts. Specific solutions have been evaluated in terms of their effectiveness in the area of requirements generated by the subsequent stages of the innovation process carried out at the university. A fourlevel scale assessing effectiveness of the solution has been used: "lack of application of the given solution at the particular stage", "poor effectiveness of the given solution", "moderate effectiveness of the given solution" or "high effectiveness of the given solution".

Table 1 presents a simplified assessment of effectiveness of the use of individual instruments in the process of creating the supply of knowledge endowed with the commercial potential. This process is a component of innovation processes within the university and is understood as a sequence of actions aimed at building the university's offer, containing specific proposals for cooperation with businesses (and more broadly with the environment), or at commercialization in the form of spin-off companies. The 
table shows a distribution of areas of activity in terms of individual entities at various stages of the innovation process. Entities that carry out simultaneously activities included in the subsequent stages of the process can be seen, however, each of these entities has solutions of main importance. Activities of the university network of scouts are largely focused on the stage associated with the search for new knowledge. In terms of its evaluation and selection, the technology transfer center dominates and in terms of commercialization of knowledge the technology transfer center along with the innovation broker play a dominant role. The final stage, referring to actions of the entities established in the framework of the commercialization process, is an area dominated by academic technology incubators.

TABLE 1.

The importance of academic units in the process of creating new ventures for commercialization of knowledge

\begin{tabular}{|l|c|c|c|c|}
\hline \multicolumn{1}{|c|}{ Academic unit } & $\begin{array}{c}\text { Search for new } \\
\text { knowledge at } \\
\text { the university }\end{array}$ & $\begin{array}{c}\text { Evaluation } \\
\text { and } \\
\text { selection }\end{array}$ & $\begin{array}{c}\text { Implementation } \\
\text { of knowledge and } \\
\text { its } \\
\text { commercialization }\end{array}$ & $\begin{array}{c}\text { After } \\
\text { transfer }\end{array}$ \\
\hline $\begin{array}{l}\text { Dean's representative } \\
\text { for business relations }\end{array}$ & + & + & - & + \\
\hline $\begin{array}{l}\text { University chancellor's } \\
\text { representative for } \\
\text { business relations }\end{array}$ & - & - & - & - \\
\hline Innovation broker & + & ++ & +++ & - \\
\hline $\begin{array}{l}\text { Publicly available } \\
\text { university databases }\end{array}$ & + & - & - & + \\
\hline $\begin{array}{l}\text { University technology } \\
\text { transfer center }\end{array}$ & + & +++ & +++ & +++ \\
\hline $\begin{array}{l}\text { Academic technology } \\
\text { incubator }\end{array}$ & & & + & - \\
\hline $\begin{array}{l}\text { University network of } \\
\text { knowledge scouts }\end{array}$ & +++ & ++ & + & \\
\hline
\end{tabular}

Comment: Description: “-” lack of application of the given solution at the particular stage, "+" poor effectiveness of the given solution, " ++ " moderate effectiveness of the given solution, " +++ " high effectiveness of the given solution

Source: [Wiśniewska, Głodek, Trzmielak, 2015]

Table 2 contains a simplified assessment of effectiveness of the use of individual instruments in the process of creating demand for knowledge endowed with the commercial potential originating from the university. This process is understood as a sequence of actions aimed at a search for partners interested in various forms of cooperation drawing on knowledge derived from the university. As shown in Table 1 , the distribution of areas of activity in terms of the respective units at different 
stages of the innovation process can be seen. In this case, the activity of the university network of scouts is largely focused on the stage associated with a search for new partners in the process of knowledge commercialization. This also includes an area realized by other entities, although in a relatively ineffective way.

TABLE 2.

The importance of academic units in the process of seeking external partners for ventures of knowledge commercialization

\begin{tabular}{|l|c|c|c|c|}
\hline \multicolumn{1}{|c|}{ Academic unit } & $\begin{array}{c}\text { Search for } \\
\text { areas of } \\
\text { cooperation } \\
\text { among potential } \\
\text { partners }\end{array}$ & $\begin{array}{c}\text { Evaluation } \\
\text { and } \\
\text { selection } \\
\text { of ideas }\end{array}$ & $\begin{array}{c}\text { Support in } \\
\text { the } \\
\text { negotiation } \\
\text { process }\end{array}$ & $\begin{array}{c}\text { After } \\
\text { establishing } \\
\text { cooperation }\end{array}$ \\
\hline $\begin{array}{l}\text { Dean's representative } \\
\text { for business relations }\end{array}$ & + & + & - & + \\
\hline $\begin{array}{l}\text { University chancellor's } \\
\text { representative for } \\
\text { business relations }\end{array}$ & + & + & - & - \\
\hline Innovation broker & + & ++ & ++ & - \\
\hline $\begin{array}{l}\text { Publicly available } \\
\text { university databases }\end{array}$ & + & - & - & - \\
\hline $\begin{array}{l}\text { University technology } \\
\text { transfer center }\end{array}$ & + & + & +++ & ++ \\
\hline $\begin{array}{l}\text { Academic technology } \\
\text { incubator }\end{array}$ & - & - & - & + \\
\hline $\begin{array}{l}\text { University network of } \\
\text { knowledge scouts }\end{array}$ & +++ & ++ & + & - \\
\hline
\end{tabular}

Comment: Description: "-" lack of application of the given solution at the particular stage, "+" poor effectiveness of the given solution, "++" moderate effectiveness of the given solution, "+++" high effectiveness of the given solution

Source: [Wiśniewska, Głodek, Trzmielak, 2015].

Focusing on key institutions at different stages of the innovation process carried out by the university, the model of managing this process can be supplemented with new elements. Figure 2 shows the main actors in the system of stages of this process indicated above:

1. "Generating knowledge" stage - researchers, research teams, faculties and departments,

2. "Search for economically useful knowledge" stage - the university network of scouts,

3. "Evaluation of acquired knowledge" stage - the technology transfer center, 
4. "Implementation/commercialization of knowledge" stage - the technology transfer center, and in the cases of commercialization through the establishment of new companies also academic technology incubators.

CHART 2.

Key activities/institutions in the simplified model of managing the innovation process at the university

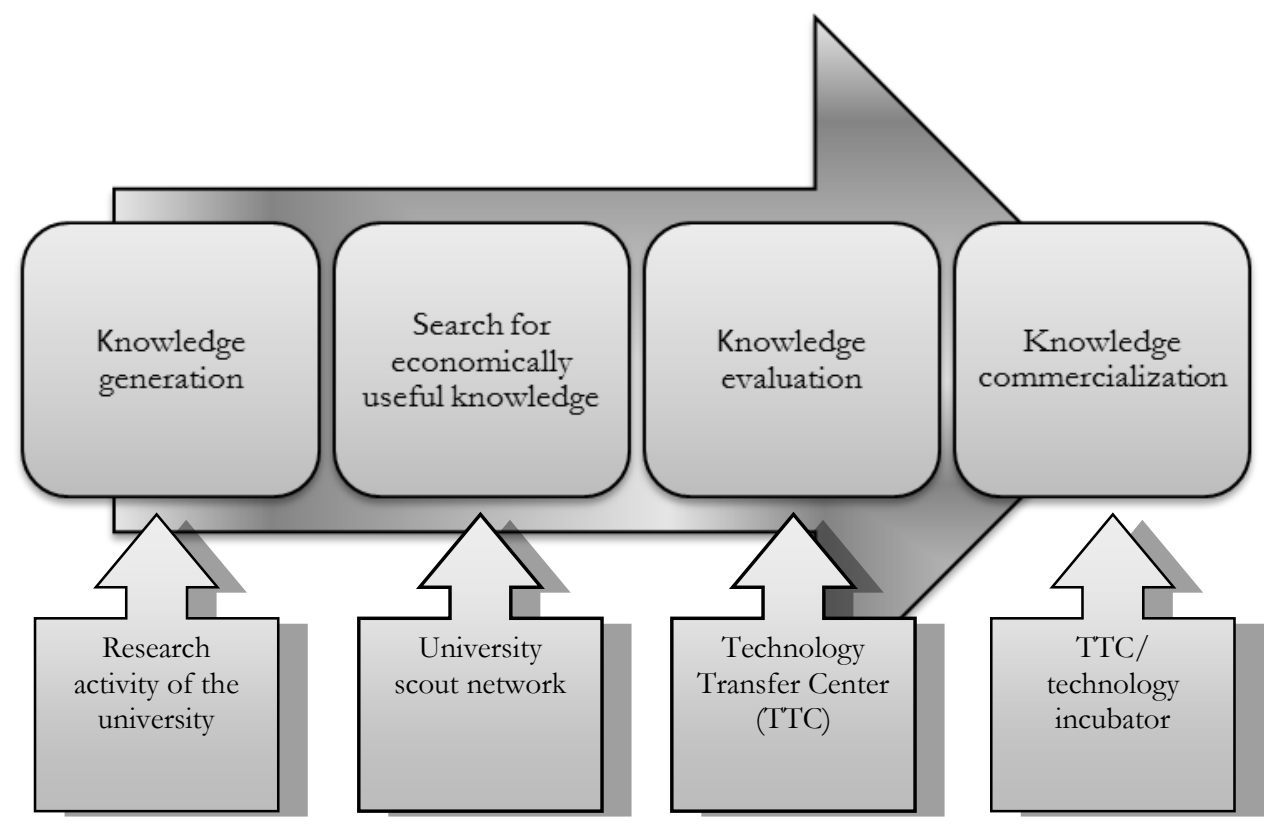

Source: [Wiśniewska, Głodek, Trzmielak, 2015].

\section{Transfer of knowledge in the universities-companies system in the region}

The basis of innovation is applicable knowledge (innovative ideas). Its acquisition is a prerequisite for implementation of innovation in an enterprise. Sources of innovation can be divided into internal ones (the entity's own sources), external ones (derived from the entity's environment) and mixed ones [Bogdanienko, 2004; Łącka, 2011]. Internal sources include solutions produced within the company and ingenuity of its employees. In the case of an innovative company, its main advantage is the exclusivity of its solutions, while high uncertainty of desired effects, long lead times and high costs are disadvantages. External sources include solutions generated outside the company, licenses, acquisitions, joint venture companies. External technical knowledge is the easiest method to obtain new solutions, effective and less risky, although it can cause dependence on technology suppliers. 
Transfer of external solutions can be described as providing the market with technologies [Jasiński, 2006]. It is a special case of a communication process. This is often an interactive process in which various feedback loops between providers and recipients of knowledge occur [Santarek, Bagiński, Buczacki, Sobczyk, Szerenos, 2008]. It covers all types of diffusion of solutions and technical education. Knowledge transfer is the transfer of the information necessary for one entity to be able to replicate the work of another entity. This information exists in two forms: technical information (engineering and scientific knowledge, standards) and procedures (including legal procedures, confidentiality agreements, patents, licenses). It is usually a market process in which technology is bought and sold. Transfer of knowledge is therefore the transfer of specific technical or organizational knowledge and related know-how for economic (commercial) purposes.

Transfer of knowledge can be differentiated into commercial and non-commercial one [Grimpe, Fier, 2010]. Non-commercial transfer includes: (1) knowledge transferred free of charge, studies, internships, etc., (2) professional associations, (3) mutual transfer of licenses, (4) knowledge transferred within companies, for example, multinationals. Commercial transfer of knowledge involves transfer of knowledge and technology between entities unrelated structurally and covers: (1) material transfer (hard), (2) trading licenses for inventions, utility models and know-how, (3) broadly understood information, including the so-called tacit knowledge.

Transfer of knowledge takes place mainly between the science and research sector and the sphere of economic activity, creating a unique bridge between these two worlds and bringing both parties many economic market, organizational, educational benefits, etc. The partners in the process of knowledge flow in different systems comprise: scientific and research institutions, large, medium and small enterprises, public institutions and individuals. A characteristic feature of cooperation between the sector of science (universities) and businesses is the presence of many cultural and organizational differences in these two spheres (different motivations, goals and methods of conducting activities, criteria for work evaluation, etc.). This creates many difficulties for the establishment and continuation of effective cooperation in the field of knowledge flow [Hewitt-Dundas, 2012].

Transfer of knowledge from the public science and research sector to companies is done through a number of channels and organizational forms [D'Este, Patel, 2007; Matusiak, 2010; Trzmielak, 2013]:

- joint research and targeted projects implemented in cooperation with businesses;

- contract research commissioned by companies;

- providing licenses for different forms of intellectual property, know-how;

- consulting, opinions, expert opinions, reviews, science and technology intermediation;

- flow of technical personnel, trainings;

- $\quad$ spin-off companies;

- $\quad$ scientific publications, popular science publications, patents;

- conferences, seminars, fairs; courses and trainings; 
- informal contacts between scientists;

- personnel mobility programs, (exchange/transition of employees from the science sector to the business sector and vice versa), student internships;

- information about new technologies, initiating the transfer;

- $\quad$ support for innovative ventures of small and medium-sized enterprises;

- initiating collaboration and cooperation networks;

- the development of the support system for innovative ventures and entrepreneurship.

A regional innovation policy plays an important role in transfer of knowledge from the public R\&D sector, including universities, to businesses [Matusiak, 2010]. In functional terms, it is a unique forum for cooperation between different types of organizations and institutions operating in the region, whose principal purpose (or one of the objectives) is the development of innovative entrepreneurship in the region. These units include: regional authorities (voivodeship, county and municipal level), regional development agencies, universities, $R \& D$ institutes, innovation centers, financial institutions, consulting, manufacturing and services companies, etc. In the framework of the regional structure, a kind of functional network connecting all entities operating in the field of innovation and technology transfer is created. A regional innovation policy is characterized by the focus on the demand aspect of innovation that requires interaction between companies, especially SMEs, and the sphere of research, science and technology. This is due to the proximity and greater confidence in the partners coming from the same area, professing the same values determined by the same cultural factors [ewtuchowicz, 2005; Nowakowska, 2010; Shane, 2005; Hewitt-Dundas, 2012]. Services for transfer of knowledge and innovation in the universities-local businesses system are provided mainly by regional institutions of the innovative business environment, as well as commercial providers, operating in the broadly understood area of entrepreneurship, innovation, technology transfer and commercialization. The status and development prospects of this sphere of economy, as well as the quality and range of services provided, have an increasingly visible impact on knowledge flows and innovativeness of individual companies and on the overall economy [Stawasz, 2009].

\section{Transfer of knowledge in the universities - businesses system in the Lodz region ${ }^{2}$}

\section{Types of knowledge transfer}

Knowledge transfer practices between universities and businesses can be divided into seven types (Chart 3). Simple, not highly developed practices dominate. Practices in

\footnotetext{
2 The paper uses the results of the empirical research conducted in 2010-11 within the framework of the international project "Innovation Policy in University City Regions - INNOPOLIS" (Program INTERREG IVC) implemented with the participation of authors derived from universities in Lodz (the University of Lodz, Lodz University of Technology and the Medical University of Lodz). For the analysis included a total of thirty-five cases of practices of knowledge transfer. Conducted reconnaissance as well as interviews and existing reports, indicates that the analysis covered the important part of such practices.
} 
the framework of cooperation in the field of training and education addressed to students, university and company employees, as well as other individuals are predominant $(40.5 \%$ of the cases). Transfer of knowledge between universities and businesses occurring in the framework of contracts, mostly research ones $(23.8 \%)$, as well as in the framework of informal cooperation which covers practices that take place without the consent of both parties $(9.5 \%)$ plays an important role. Informal cooperation usually applies to the use of research results and research infrastructure free of charge and without the university's consent, as well as trainings conducted on the premises of the university.

CHART 3.

Key activities/institutions in the simplified model of managing the innovation process at the university

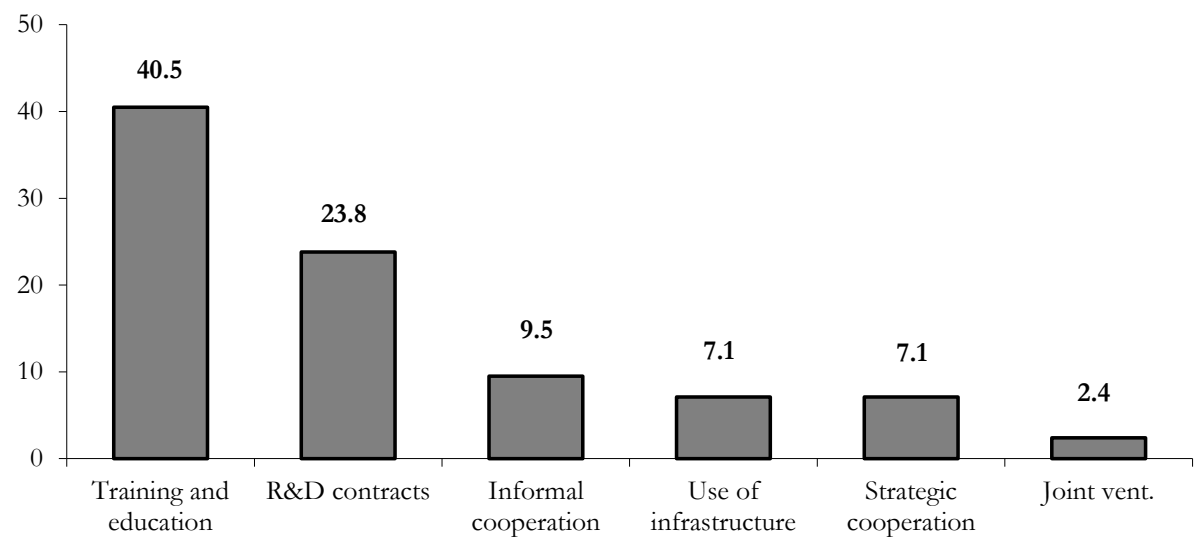

Source: author's own work.

Other types of knowledge transfer between universities and businesses occur much less frequently. Transfer of knowledge in the framework of the use of infrastructure ( $7.1 \%$ of the cases) as well as in the framework of strategic cooperation between universities and businesses (only three cases $-7.1 \%$ ) can be mentioned. In just one case, there was an exchange of knowledge between universities and businesses in the framework of joint venture, considered a very advanced form of knowledge transfer.

\section{The initiative of knowledge transfer}

Knowledge transfer practices between universities and businesses in the Lodz region were initiated from the top in the context of the policy to encourage innovation in the region, either by universities or by companies themselves. The analysis of the forms of initiating practices of knowledge transfer between universities and businesses in the Lodz region shows that they are initiated primarily by universities $(67.6 \%$ of the cases), mainly within the framework of various types of programs of cooperation with the regional economy. Every sixth case (18.9\%) resulted from the initiative on the part 
of companies, every seventh case was initiated within the framework of programs to support innovation in the region (13.5\%). Among the seven cases initiated by companies, there are four cases conducted in the framework of cooperation based on a contractual (research) agreement and three cases arising from informal cooperation. However, among the five cases initiated by innovation support programs, there are four cases implemented under research contracts and one case involving trainings and education.

\section{The duration of knowledge transfer practices}

Knowledge transfer practices between universities and businesses in the Lodz region were analyzed in terms of their duration and reproducibility (in other circumstances and institutions). In terms of the issue of duration of the practices, they are divided into two groups: long-term (with a duration of more than 6 months) and short-term (less than 6 months). The analysis conducted shows that short-term practices are dominant $4 / 5$ of the total number of cases. Long-term practices, hence the most useful for knowledge transfer, constitute only $1 / 5$ of the total number of cases. All of these cases concerned transfer of knowledge between universities and businesses carried out in the framework of contracts or long-term strategic cooperation.

More than $4 / 5$ of all the cases $(82.6 \%)$ are reproducible, which means that they can be used in other circumstances and by other entities. They can be, therefore, disseminated in the Lodz region as the so called "good practices". Only 17.4\% of the cases were irreproducible, difficult to disseminate. This concerned mainly cases of knowledge transfer between universities and businesses in the framework of informal cooperation.

\section{The scope of knowledge transfer}

In the case of the subjective scope of knowledge transfer practices between universities and businesses, the analysis has highlighted two kinds of scope, i.e. direct cooperation between the two parties and cooperation with the participation of a third party, e.g.: government offices, other stakeholders. The cooperation in the framework of which only transfer of knowledge between universities and businesses occurs is dominant (77.1\% of the cases). A larger number of participants can only be found in $22.9 \%$ of the cases. Half of the cases involved activities carried out under contracts.

\section{Effects of knowledge transfer impact}

Regarding effects of the analyzed practices of knowledge transfer between universities and businesses in the region, direct effects in the form of flow of knowledge and indirect effects associated with initiating the flow of knowledge can be distinguished. The conducted analysis of knowledge transfer practices between universities and businesses in the region indicates that indirect effects dominate $(62.9 \%$ of the cases). Direct transfer of knowledge took place only in slightly more than $1 / 3$ of the cases. This indicates weakness of knowledge transfer between universities and businesses in the region. Only every third case of cooperation yielded a direct flow of knowledge. These cases involve cooperation in the framework of contracts, informal cooperation and 
strategic cooperation, and thus long-term projects. The remaining $2 / 3$ are the cases concerning a potential flow of knowledge -the initiation of this process.

\section{Risks and benefits of knowledge transfer}

The analysis indicates that knowledge transfer practices between universities and businesses in the Lodz region are associated with a small risk of failure - this applies to $70 \%$ of the analyzed practices in the case in which no or minimal risk of failure exists. Only 30\% of the analyzed practices were affected by the risk of failure considered as medium. A noticeable risk of failure takes place mainly in the following cases:

- cooperation undertaken with the participation of a third party, e.g. business support institutions, technology transfer institutions, government agencies ( $80 \%$ of the practices of this type),

- cooperation initiated within the top-down (formal) approach in which both parties, i.e. the university and the company, are somehow "compelled" to cooperate in the exchange of knowledge (60\% of the cases),

- cooperation carried out in the framework of research contracts generally burdened with a great risk of failure.

Transfer of knowledge between universities and businesses allowed both parties, i.e. universities and businesses, to obtain a number of scientific and research, educational, economic, organizational and market benefits. Relatively more benefits were obtained by companies $(97 \%)$ than universities $(88 \%)$.

Both parties have indicated different types of benefits derived from knowledge transfer:

1. In the case of companies, the following benefits are primarily derived:

a. scientific and research benefits related to obtaining new or improved knowledge by the company ( $43 \%$ of the companies); it should be noted that the acquired knowledge in most cases has been applied in practice ( $60 \%$ of this type of companies), which is the evidence of high practical value of knowledge transfer;

b. organizational benefits related to skills of personnel and the improvement of operational strategy ( $34 \%$ of the companies);

c. economic benefits related to the improvement of economic performance, e.g. reduced production costs, payments for services rendered ( $23 \%$ of the companies);

d. market benefits related to commercialization of knowledge and the improvement of the company's market position ( $6 \%$ of the companies).

2. In the case of universities, the following benefits are primarily derived:

a. economic benefits, e.g. payments for services rendered ( $43 \%$ of the universities);

b. educational benefits, mainly related to the possibility of organizing internships for students in companies ( $43 \%$ of the universities); 
c. scientific and research benefits related to the development of knowledge in cooperation with companies, e.g. testing and laboratory research of technologies in companies ( $20 \%$ of the universities);

d. organizational benefits related to the development of scientific staff ( $9 \%$ of the universities);

e. market benefits related to commercialization of knowledge created at universities ( $6 \%$ of the universities).

The above-presented review of benefits obtained as a result of knowledge transfer indicates that both parties receive benefits. Universities, however, tend to point to economic and educational benefits, whereas companies mention scientific and research benefits as well as organizational ones.

\section{Conclusions}

The paper provides an analysis of the process of creating the university's potential in terms of its ability to transfer knowledge to the business environment. A relationship between processes of knowledge generation as well as innovation processes and the institutional system operating within the university has been shown. The understanding of this system is important due to the significant interdependence of individual stages of the process in terms of ability to generate results in the form of knowledge transfer.

The paper uses the results of the study of knowledge transfer practices among three largest universities in Lodz. The study indicated primarily the use of simple, not highly developed practices. In particular, such practices that do not require significant changes in the operation of the university's individual organizational units. Strategic, long-term cooperation is very rarely encountered and short-term cooperation, not exceeding six months, prevails. This fact can be associated with the perception on the part of companies of the relationship with the university in the context of heightened risk [Poznańska et al., 2012], which may limit their tendency to deeper commitment to cooperation.

Implemented practices are most often reproducible, which means that they can be used in other contexts and by other entities. They can thus be disseminated in the region of Lodz as the so called "good practices". Cooperation in the framework of which only transfer of knowledge between universities and businesses occurs is dominant. Effects of these practices are mostly indirect, providing only the initiation of the process of knowledge transfer.

The review of benefits derived from transfer of knowledge indicates that both parties obtain benefits. Universities tend to point to economic and educational benefits, whereas companies indicate scientific and research as well as organizational benefits.

The overall structure of universities-businesses cooperation indicates a certain weakness of knowledge transfer between the partners in the Lodz region. In practical terms, the identified transfer profile shows the need to strengthen internal processes preparing universities in the region for transfer of knowledge. This strengthening, relating to internal structures, should aim at increasing the university's potential to create stable, long-term and strategic relationships with partners in the economic environment. 


\section{References}

Bessant J., Oberg C., Trifilova A. 2014 Framing Problems in Radical Innovation, "Industrial Marketing Management", Vol. 43.

Bogdanienko J. 2004, Innowacyjność przeedsiębiorstw, Wydawnictwo UMK, Toruń.

Cieślik J. 2014 Przedsiebiorczość, polityka, rozwoój, Wydawnictwo Akademickie SEDNO, Warszawa.

D'Este P., Patel P. 2007 University - Industry Linkage in the UK: What Are the Factors Underlying the Variety of Interactions with Industry?, "Research Policy", No. 36.

Drucker J., Goldstain H. 2007 Assessing the Regional Economic Development Impacts of Universities: A Review of Current Approaches, "International Regional Science Review", 30 (1).

Etzkowitz H., Webster A., Gebhardt Ch., Cantisano Terra B. R. 2000 The Future of the University and the University of the Future: Evolution of Ivory Tower to Entrepreneurial Paradigm, "Research Policy", Vol. 29, No. 2.

Głodek P., Wiśniewska M. 2015 Ucz̨elniany scouting wiedży, jako element systemu komercjalizacji wiedsy w ramach uczelni wy ¿̇szej, Ekonomiczne Problemy Usług, Zeszyty Naukowe Uniwersytetu Szczecińskiego, Szczecin, (in print).

Grimpe Ch., Fier H. 2010 Informal University Technology Transfer: A Comparison between the United States and Germany, "Journal of Technology Transfer", No. 35.

Handoko F., Smith A., Burvill C. 2014 The Role of Government, Universities, and Businesses in Advancing, Technology for SMEs' Innovativeness, "Journal of Chinese Economic and Business Studies", Vol. 12, No. 2, http://dx.doi.org/10.1080/14765284.2014.900968.

Hewitt-Dundas N. 2012 Research Intensity and Knowledge Transfer Activity in UK Universities, "Research Policy", 41 (2).

Hughes A., Kitson M. 2012 Pathways to Impact and the Strategic Role of Universities: New Evidence on the Breadth and Depth of University Knowledge Exchange in the UK and the Factors Constraining its Development, "Cambridge Journal of Economics", Vol. 36, DOI: $10.1093 /$ cje/bes017.

Jasiński A. H. 2006 Innowacje i transfer techniki w procesie transformacji, Difin, Warszawa.

Jewtuchowicz A. 2005 Terytorium i wspótczesesne dylematy jego rozpooju, Wydawnictwo Uniwersytetu Lódzkiego, Łódź.

Krogh G. von 1998 Care in Knowledge Creation, "California Management Review". Vol. 40.

Lawton Smith H., Ho K. 2006 Measuring the Performance of Oxford University, Oxford Brookes University and the Government Laboratories' Spin-off Companies. "Research Policy", 35 (10).

Łącka I. 2011 Wspótpraca technologiczna polskich instytucji nankowych i badawcsych z.przedsiebiorstwami jako caynnik wærostu polskiej gospodarki, Wydawnictwo Uczelniane Zachodniopomorskiego Uniwersytetu Technologicznego, Szczecin.

Łobacz K., Niedzielski P. 2015 Uczelnie wy ższe, jako element procesu komercjalizacji wiedzy w Polsce - uyzwania $i$ bariery, [in:] Budowa potencjału uczelni wy ższej do wspótpracy z przedsiebiorstwami. Rola scoutingu wiedsy, P. Głodek, M. Wiśniewska (ed.), Wydawnictwo Uniwersytetu Lódzkiego, Łódź, pp. 81-103. 
Matusiak K. B. 2010 Budowa powiqzań nauki z. biznesem w gospodarce opartej na wiedzy. Rola uniwersytetu w procesach innowacyjnych, Wydawnictwo Szkoły Głównej Handlowej, Warszawa.

Morawski M. 2005 Problematyka upowszechniania wiedzy miedzy jednostkami organizacyjnymi uczelni, [in:] Uczelnia oparta na wiedzy. Organizacja procesu dydaktycznego oraz zarzqdzanie wiedzq w ekonomicznym szkolnictwie wyższym, T. Gołębiowski, M. Dąbrowski, B. Mierzejewska (eds.), Fundacja Promocji i Akredytacji Kierunków Ekonomicznych, Warszawa.

Niedzielski P., Łobacz K. 2012 Diagnoza i analiza problemów komercjalizacji wiedzy i transferu technologii na uczelni wyższej pod keatem barier natury organizacyjnej, ekspertyza praygotowana w ramach projektu "SCOUTING - aketywny system monitoringu i oceny potencjału rynkowego prac badawczych kluczem do wspótpracy nauki i przedsiębiorców, maszynopis powielony, Szczecin.

Nowakowska A. 2011 Regionalny wymiar procesów innowacji, Wydawnictwo Uniwersytetu Łódzkiego, Łódź.

Poznańska K., Zarzecki M., Matuszewski P., Rudowski A. 2012 Innowacyjność prz̨edsiębiorstw na Mazowszu oraz współpraca ze szkołami wyższymi, Politechnika Warszawska, Warszawa.

Probst G. 1998 Practical Knowledge Management: A Model That Works, Prism, Second Quarter, Arthur D. Little.

Rossi F., Rosli A. 2014 Indicators of University-Industry Knowledge Transfer Performance and their Implications for Universities: Evidence from the United Kingdom, "Studies in Higher Education", http://dx.doi.org/10.1080/03075079.2014.914914

Santarek K., Bagiński J., Buczacki A., Sobczyk D., Szerenos A. 2008 Transfer technologii z. uczelni do biznesu. Tworzenie mechanizmów transferu technologï, Polska Agencja Rozwoju Przedsiębiorczosci, Warszawa.

Shane S. 2005 Government Policies for Encourage Economic Development through Entrepreneurship: The Case of Technology Transfer, [in:] Economic Development through Entrepreneurship. Government, University and Business Linkages, S. Shane (ed.), Elgar, Cheltenham.

Stawasz E. 2009 Realizacja i integracja polityki innowacyjnej i przedsiebiorczości (wybrane problemy na praykktadzie regionu tódzkiego), [in:] Budowanie zdolności innowacyjnych regionów, (ed.) A. Nowakowska, Wydawnictwo Uniwersytetu Lódzkiego, Lódź.

Tidd J., Bessant J., Pavitt K. 2005 Managing Innovation. Integrating Technological Market and Organizational Change. John Wiley \& Sons Ltd.

Trzmielak D. 2013 Komerjalizacja wiedsy $i$ technologii - determinanty i strategie, Wydawnictwo Uniwersytetu Łódzkiego, Łódź.

Wiśniewska M., Głodek P., Trzmielak D. 2015 Wdrażanie scoutingu wiedzyy w polskiej uczelni wy ższej. Aspekty praktyczne, Wydawnictwo Uniwersytetu Lódzkiego, Lódź.

Woźniak P. 2015 Podejście procesowe w systemie zarzqdzania uczelnia, the paper presented at the XVIII Conference entitled "Innowacje w zarządzaniu i inżynierii produkcji", Zakopane, 01-03 March. 